\title{
Factors Affecting the Digestibility of Beef and Consequences for Designing Meat-Centric Meals
}

\author{
Mustafa M. Farouk (iD, ${ }^{1}$ Guojie Wu, ${ }^{1}$ Deborah A. Frost, ${ }^{1}$ Maryann Staincliffe, ${ }^{1}$ \\ and Scott $\mathrm{O}$. Knowles (iD $^{2}$ \\ ${ }^{1}$ AgResearch Ltd, Ruakura Research Centre, Private Bag 3123, Hamilton, New Zealand \\ ${ }^{2}$ Food \& Bio-based Products Group, AgResearch Ltd, Palmerston North, New Zealand
}

Correspondence should be addressed to Mustafa M. Farouk; mustafa.farouk@agresearch.co.nz

Received 8 March 2019; Revised 24 May 2019; Accepted 3 July 2019; Published 7 August 2019

Guest Editor: Lara Morán

Copyright (C) 2019 Mustafa M. Farouk et al. This is an open access article distributed under the Creative Commons Attribution License, which permits unrestricted use, distribution, and reproduction in any medium, provided the original work is properly cited.

\begin{abstract}
The impact of the following on beef digestibility was determined by static in vitro methods: (1) age of cattle; (2) muscle rigor state, ultimate $\mathrm{pH}$, and mincing/particle size; (3) muscle/meat cut; (4) organ meats; and (5) meat accompaniments. Results indicate that beef is more digestible from older compared to younger cattle; prerigor compared to postrigor meat; higher compared to lower ultimate $\mathrm{pH}$ meat; cuts with lower compared to higher collagen contents; finely compared to coarsely minced/ground meat; and organ (liver and kidney) compared to muscle meat. Beef digestibility is enhanced when cooked with mushroom and pumpkin and reduced with starchy foods such as rice and potatoes. The outcomes of this study provide a base for the scientific design of meals with beef as a central ingredient and digestibility as the main functionality of interest.
\end{abstract}

\section{Introduction}

For years, the field of meat science has prioritised research on meat as a standalone entity, with the aim of describing its table and manufacturing qualities, composition and nutrient density. Much less is known about its attributes in the context of whole meals where meat is just one of the several ingredients or in meat-rich foods that are designed with specific functionality or consumers in mind. Incentives for understanding how meat performs in complex matrices are increasing due to recent growth of the "meal kit" industry and demand for all in one meal solutions at retail outlets. Information about this central ingredient would assist in the design of meals to optimise processing and packaging requirements and to deliver better eating experiences and nutrition.

A key functionality of meat, whether eaten alone or in food combinations, is its digestibility. This has relevance to consumers across a wide range of demographics, physiologies, and lifestyles. Indeed, all desirable nutritional benefits of meat hinge first on adequate digestion. This is not a fixed attribute, as it is influenced by intrinsic and extrinsic factors such as animal rearing method [1], cooking methods and temperatures [2-5], oxidation [3], as well as ageing and $\mathrm{pH}$ [6]. Our current work extends research on the digestibility of muscle and organ meats by considering the inherent characteristics of those tissues and cuts, and the effects of accompaniments that are most commonly served in meatcentric meals. Outcomes could be used by meat producers, butchers, and chefs to tailor the merchandising of meat dishes around digestibility and not solely on aesthetic-gustatory considerations.

In this paper, we describe a linked series of experiments on intrinsic and extrinsic factors that can affect the in vitro digestibility of cooked beef: (1) age of cattle; (2) muscle rigor state, ultimate $\mathrm{pH}$, and mincing/particle size; (3) muscle/ meat cut; (4) organ meats; and (5) meat accompaniments. Our goal is to provide data to support the rational design of meals suited to groups of consumers who might benefit from different levels of digestibility.

\section{Materials and Methods}

2.1. Main Characteristics of Animal Samples. All animals were sourced from commercial or research farms in New 
Zealand, where feeding systems are typically free-range grazing on ryegrass/clover pastures with occasional supplements of conserved forages. The genetic background of the animals was primarily Friesian for the dairy-based livestock classes and Angus $\times$ Hereford for prime beef.

For these experiments, cows were end-of-service cull dairy cattle aged 6 years. Bulls were noncastrated male dairy cattle aged 18-24 months. Calves were unweaned male dairy cattle aged 4-14 days, which is considered "veal" in some markets. Prime beef steers and heifers were castrated male and unmated female beef cattle aged 24-30 months. All animals were slaughtered and processed at licensed commercial abattoirs.

\subsection{Trial Details}

2.2.1. Experiment 1. To investigate the effect of age of cattle, legs from seven cows, seven bulls, and seven calves were collected. The legs were held for $24 \mathrm{~h}$ at $8^{\circ} \mathrm{C}-10^{\circ} \mathrm{C}$ to achieve rigor and then kept in a chiller $\left(-1.5^{\circ} \mathrm{C}\right)$ over the weekend. For each leg, the semimembranosus (SM) muscle was dissected and the postrigor $\mathrm{pH}$ measured. A $100 \mathrm{~g}$ sample was minced using a food processor, and the remaining muscle was frozen at $-30^{\circ} \mathrm{C}$. Pooled samples of cow, bull, and calf were prepared by mixing $10 \mathrm{~g}$ of the mince from each of the seven animals. Subsamples of the 21 individual muscles and the three pooled samples were set aside for protein determination, and the remainders were frozen at $-30^{\circ} \mathrm{C}$. The pooled and individual samples $(n=24)$ were used for in vitro digestibility measurements (gastric and intestinal phases) as described in Section 2.5.

2.2.2. Experiment 2. To investigate the effect of rigor state, M. longissimus dorsi (loin, LD) from 48 bulls was collected at approximately $50 \mathrm{~min}$ postmortem. For each LD, a slice was taken, chopped into $1 \mathrm{~cm}^{3}$ pieces, placed on a plastic film, and then snap-frozen in liquid nitrogen. This material was transferred to plastic containers and kept under liquid nitrogen until transferred to a freezer $\left(-30^{\circ} \mathrm{C}\right)$. The balance of each $\mathrm{LD}$ was held at approximately $7^{\circ} \mathrm{C}$ and sampled again at $80,110,140,170$, and $200 \mathrm{~min}$ by the above protocol. The remnant of each $\mathrm{LD}$ was transferred to a chiller $\left(-1.5^{\circ} \mathrm{C}\right)$, and a final postrigor sample was taken at $48 \mathrm{~h}$ postmortem, at which time, ultimate $\mathrm{pH}$ was also measured.

To investigate the effect of ultimate $\mathrm{pH}$, seven of the $\mathrm{LD}$ were selected based on their ultimate $\mathrm{pH}$ to provide a $\mathrm{pH}$ range of 5.6 to 6.9. Two were low $\mathrm{pH}$ (i.e. $\leq 5.8$ ), two were intermediate $\mathrm{pH}(\mathrm{pH}$ 5.81-6.2), and three were high $\mathrm{pH}$ $(>6.2)$. For each of these, all seven timepoints (six prerigor and one postrigor) were used $(n=49)$. Samples were ground to a powder under liquid nitrogen using a SPEX Freezer/ Mill ${ }^{\circledR}$ cryogenic grinder just prior to gastric phase digestibility measurements.

To investigate the effect of particle size, the two LD with low ultimate $\mathrm{pH}$ (i.e. $\leq 5.8$ ) were selected and their $50 \mathrm{~min}$ prerigor and $48 \mathrm{~h}$ postrigor timepoints were used. These were either ground to powder using the SPEX Freezer/Mill ${ }^{\circledR}$ or smashed coarsely with mortar and pestle just prior to digestibility measurements.
2.2.3. Experiment 3. To investigate the effect of muscle type or meat cut, the rhomboideus, infraspinatus, supraspinatus, and extensors/flexors from five prime heifers were collected. Each muscle/cut from each animal was separately minced through a $3 \mathrm{~mm}$ plate and thoroughly homogenised, then subsampled, and stored at $-30^{\circ} \mathrm{C}$ until digestibility measurements.

2.2.4. Experiment 4. To compare organ versus muscle meats, heart, kidney, spleen, and liver meat and muscle meat (M. semitendinosus, eye of the round) from five prime steers were collected, and the surface fat was removed. The tissues were minced through a $3-\mathrm{mm}$ plate and stored at $-30^{\circ} \mathrm{C}$ until digestibility measurements.

2.2.5. Experiment 5. To understand digestibility of meat in the context of a meal, we first investigated which nonmeat (cereal or vegetable) accompaniments are most commonly served with red meat meals. An internet search of restaurants was carried out. A total of 101 and 120 restaurants in New Zealand and Australia, respectively, were selected that had a web presence, published their menus online, and served at least one dish in which accompaniments were cooked with a red meat or served alongside. Eligible meats were beef, lamb, calf veal, goat, venison, kangaroo, wallaby, and rabbit. The restaurants were distributed across the countries. In Australia, for instance, menus were studied from twenty restaurants in each of six cities: Brisbane (Queensland), Adelaide (South Australia), Melbourne (Victoria), Perth (Western Australia), Sydney (New South Wales), and Hobart (Tasmania). From the results of the survey, the most common accompaniments were tallied from the frequencies of their appearance in the menus (Figure 1). The top five accompaniments in the survey plus one additional vegetable of interest (pumpkin) were selected for consideration of their effects on the gastric and intestinal phases of beef digestibility.

Mushrooms (button, Agaricus bisporus), onions, potatoes (Nadine), rice (Calrose and SunRice Australian medium grain), tomatoes, and pumpkin (buttercup, Curcubita maxima kabocha) were purchased from a local supermarket. The raw foods were prepared as follows:

(i) Mushrooms: peeled, stalks trimmed, sliced, and blended in a food processor

(ii) Onions: peeled, chopped, and blended in a food processor

(iii) Potatoes: peeled, chopped, and blended in a food processor

(iv) Rice: ground to powder in a Waring blender

(v) Tomatoes: chopped and blended in a food processor (skin on)

(vi) Pumpkin: removed skin, deseeded, and blended in a food processor

The pooled samples from Experiment 1 of minced SM from either cow, bull, or calf were each combined with each of the accompaniments $(3 \times 6=18$ treatment combinations $)$ 


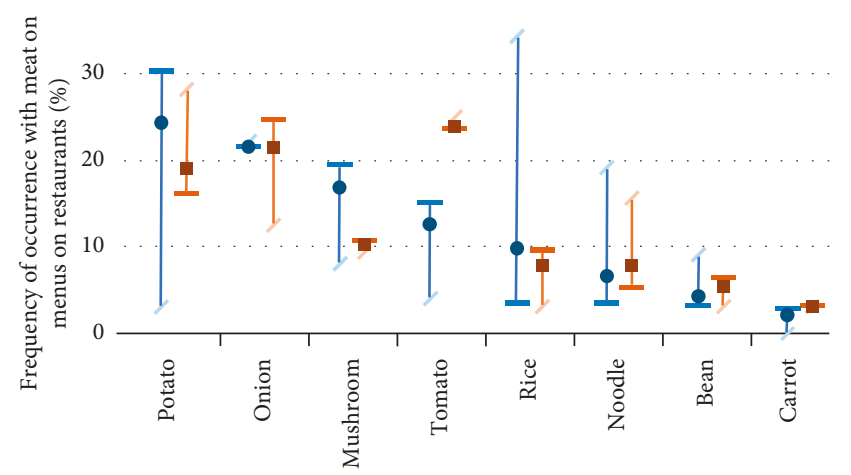

New Zealand restaurants

- All $(n=101)$

- European (82)

Asian (19)

$$
\begin{aligned}
& \text { Australia restaurants } \\
& \text { - All }(n=120) \\
& - \text { European (92) } \\
& \text { Asian (28) }
\end{aligned}
$$

FIGURE 1: Experiment 5: summary of results from the online survey of accompaniments to meat, as described on menus in New Zealand and Australia restaurants.

in a $1: 2 \mathrm{w} / \mathrm{w}$ ratio of meat and accompaniment. Unaccompanied meats served as controls. The various meats were weighed into $100 \mathrm{ml}$ Schott bottles to give the equivalent of $875 \mathrm{mg}$ protein (3.7 to $4.5 \mathrm{~g}$ of raw meat) and cereal/ vegetable added at $2 \times$ weight of meat. Total volume (including the volume of water contributed by the vegetables) was adjusted to $25 \mathrm{ml}$ with deionised water. The mixture was homogenised using an IKA Ultra-Turrax ${ }^{\circledR}(13,500 \mathrm{rpm}$ for $30 \mathrm{sec}$ ) and the shaft rinsed back into the Schott bottle with $5 \mathrm{ml}$ of deionised water. The resulting slurry was placed on a laboratory shaker in the refrigerator overnight $\left(4^{\circ} \mathrm{C}\right)$.

The following day, the slurries were cooked in a waterbath $\left(100^{\circ} \mathrm{C}\right)$ for $30 \mathrm{~min}$ and then homogenised using the Ultra-Turrax to break up the lumps formed during cooking. Concentrated $\mathrm{HCl}$ was added to bring the acid content to $0.1 \mathrm{M}$. The slurries were diluted with $0.1 \mathrm{M}$ HCL to a volume slightly less than that required to achieve a protein concentration of $23 \mathrm{mg} / \mathrm{ml}$, then the $\mathrm{pH}$ was adjusted with $6 \mathrm{~N} \mathrm{NaOH}$ to $\mathrm{pH} \mathrm{1.9,} \mathrm{and} \mathrm{the} \mathrm{total} \mathrm{volume} \mathrm{was} \mathrm{topped} \mathrm{up} \mathrm{to}$ reach $23 \mathrm{mg} / \mathrm{ml}$.

2.3. $\mathrm{pH}$ Measurements. Ultimate $\mathrm{pH}$ of the meats used in Experiments 1 and 2 was measured using a Hanna $\mathrm{pH}$ meter (\#HI99163) as previously described [6]. The $\mathrm{pH}$ of the meats used in the other experiments and for the slurries in Experiment 5 was measured using a Mettler Toledo MP 220 meter equipped with a Mettler Toledo InLab pH probe.

2.4. Protein Content of Meat. The protein content of muscles and organs in Experiments 1 and 4 was determined from total $\mathrm{N}$ using AOAC methods by a commercial analytical service (Eurofins Ltd, Hamilton, NZ).

\subsection{Zymography Analysis of Protease Activity in} Accompaniments. Proteolytic enzymes in the accompaniment foods of Experiment 5 may contribute to the efficiency of in vitro digestion of meat. The raw foods were prepared as above and enzymes extracted as described by Pirovani et al.
[7]. In brief, $100 \mathrm{~g}$ of each raw material was suspended in $100 \mathrm{ml}$ of prechilled extraction buffer (Tris- $\mathrm{HCl} 10 \mathrm{mM} \mathrm{pH}$ 7.5, Triton X-100 1\%, and EDTA $5 \mathrm{mM}$ ) except for rice (200 $\mathrm{ml}$ buffer) and tomato $(50 \mathrm{ml}$ buffer). These samples were homogenised using the Ultra-Turrax at 19,000 rpm for $2 \mathrm{~min}$ in an ice bath. Thereafter, the samples were sonicated for $10 \mathrm{~min}$, vortexed, and centrifuged at $10,000 \times g$ for $10 \mathrm{~min}$ at $4^{\circ} \mathrm{C}$. The supernatants were saved. All procedures were carried out in a refrigerated room $\left(2^{\circ} \mathrm{C}-4^{\circ} \mathrm{C}\right)$.

Casein zymography was carried out on the extracts according to manufacturer's instruction. Four volumes of each extract were mixed with 1 volume of $5 \mathrm{X}$ sample loading buffer (50\% glycerol, 10\% SDS, $0.1 \%$ bromophenol blue and 150 mM Tris-HCl; pH 6.8). Gels were 4-16\% Novex Zymogram Blue Casein prestained gels (Thermo Fisher Scientific). The extracts ( $30 \mu \mathrm{l}$ each) and standard enzyme controls of approximately $0.1 \mu \mathrm{g}$ each (protease, Sigma P-5255; protease calcium-activated, Sigma P-4523; papain, Sigma, P-3375) were loaded onto lanes and run at $125 \mathrm{~V}$ constant voltage with running buffer (192 mM glycine, $0.1 \%$ SDS, and $25 \mathrm{mM}$ Tris) at $4^{\circ} \mathrm{C}$. After $120 \mathrm{~min}$, the gel was removed and incubated in zymogram renaturing buffer (2.5\% Triton $\mathrm{X}-100)$ with slow shaking for $30 \mathrm{~min}$. The renaturing buffer was discarded, and the gel was incubated in developing buffer $200 \mathrm{ml}(50 \mathrm{mM}$ Tris-base, $200 \mathrm{mM}$ $\mathrm{NaCl}, 5 \mathrm{mM} \mathrm{CaCl}$, and 0.02\% Brij-35, pH 7.5 adjusted with $\mathrm{HCl})$ for $30 \mathrm{~min}$ with slow shaking. The buffer was then discarded, and the gel was incubated further in $200 \mathrm{ml}$ of the developing buffer overnight with gentle shaking at ambient temperature. Finally, the gel was washed with deionised water. Areas of protease activity were identified by cleared zones in the prestained gels.

2.6. In Vitro Digestion. The digestibility of meat proteins was determined as previously described by Farouk et al. [6] using a static in vitro method that simulated the gastric and intestinal phases of digestion. This approach is widely employed, and the results obtained are indicative of outcomes of digestion in vivo $[8,9]$. Gastric digestion (pepsinbased, representing the stomach) was applied to Experiment 2, while gastric and intestinal digestion (pancreatin-based, representing the upper gastrointestinal tract (GIT)) was applied to Experiments 1, 3, 4, and 5.

2.6.1. Gastric Digestion. For most muscle and organ meats, approximately $4.5 \mathrm{~g}$ of a sample was weighed into a $100 \mathrm{ml}$ glass Schott bottle, sealed, and placed in a boiling waterbath for $15 \mathrm{~min}$ with intermittent mixing by swirling. The cooked sample was allowed to cool, covered with $34 \mathrm{ml}$ of $0.1 \mathrm{M} \mathrm{HCl}$, and then homogenised using the Ultra-Turrax for $1 \mathrm{~min}$. The $\mathrm{pH}$ was adjusted to 1.9 with $6 \mathrm{~N} \mathrm{NaOH}$ and made up to $36 \mathrm{ml}$ with deionised water. Note that special attention was paid to the prerigor meat samples from Experiment 2 because these were susceptible to spontaneous glycolysis unless kept frozen until the moment of cooking. For these, approximately $4.5 \mathrm{~g}$ of a sample was weighed into a cold Schott bottle and immediately doused with $34 \mathrm{ml}$ of boiling water and then placed in the boiling waterbath for $120 \mathrm{sec}$. The cooked 
sample was allowed to cool and its concentration brought to $0.1 \mathrm{M}$ with concentrated $\mathrm{HCl}$ and then homogenised using the Ultra-Turrax. The $\mathrm{pH}$ was adjusted to 1.9 with $6 \mathrm{~N} \mathrm{NaOH}$ and made up to $36 \mathrm{ml}$ with deionised water. For the meats combined with accompaniments from Experiment 5, the prepared slurries were already cooked, so these were used as is in their Schott bottles.

Samples were incubated in a shaking waterbath at $37 \pm 0.2^{\circ} \mathrm{C}$ for $15 \mathrm{~min}$. Two $\mathrm{ml}$ of pepsin solution (Sigma P6887, $1.575 \mathrm{mg} / \mathrm{ml}$; enzyme:substrate ratio $1: 280$ in $0.1 \mathrm{M}$ $\mathrm{HCL}$, equivalent to $12.5 \mathrm{U} / \mathrm{mg}$ protein) was added to start the proteolysis. Controls were prepared using cooked meat and $0.1 \mathrm{M}$ HCL without pepsin. An aliquot of $500 \mu \mathrm{l}$ was withdrawn immediately (T0) and again at planned timepoints. Enzyme activity in each aliquot was quenched by raising the $\mathrm{pH}$ to 8 by the addition of $1 \mathrm{M} \mathrm{NaOH}(37-39 \mu \mathrm{l})$. An equal volume of $2 \mathrm{X}$ Laemmli loading buffer containing $5 \%$ mercaptoethanol was added. The mixture was immediately vortexed, heated for $5 \mathrm{~min}$ in a waterbath at $95^{\circ} \mathrm{C}$, and then stored at $-20^{\circ} \mathrm{C}$. After $120 \mathrm{~min}$ (T120), the remaining "digesta" in the Schott bottle was adjusted to $\mathrm{pH} 8$ using $6 \mathrm{M}$ $\mathrm{NaOH}$ to inactivate the pepsin and prepare the sample for intestinal phase digestion.

2.6.2. Intestinal Digestion. Pancreatin (Sigma P8096, $2.2 \mathrm{ml}$ of $4 \mathrm{mg} / \mathrm{ml}$, enzyme:substrate ratio $1: 100 \mathrm{w} / \mathrm{w}$ in $0.1 \mathrm{M}$ phosphate buffer, $\mathrm{pH} 8$ ) was added to the Schott bottle and digestion allowed to proceed for further $2 \mathrm{~h}$, with aliquots withdrawn at intervals. Enzyme activity in each aliquot was quenched by lowering the $\mathrm{pH}$ to 2 by the addition of $6 \mathrm{M}$ $\mathrm{HCl}$. Laemmli loading buffer protocol was then followed as above.

2.7. Gel Electrophoresis. Proteins and peptides in the digesta collected during in vitro digestion were separated by 1D SDS PAGE as described by Farouk et al. [6]. For most experiments, the Laemmli-prepared aliquots were thawed and then centrifuged for $5 \mathrm{~min}$ at $9,300 \times g$ at room temperature. The supernatants were loaded at $40 \mu \mathrm{g}$ protein per lane onto Criterion TGX 10-20\% gels (Bio-Rad \#567-1114) running in Tris-glycine buffer at $120 \mathrm{~V}$ constant voltage. Gels were stained using Coomassie Blue R-250 followed by destaining with $30 \%$ methanol and $10 \%$ acetic acid in deionised water.

For Experiment 5 which combined beef with nonmeat accompaniments, $20 \mu \mathrm{g}$ protein per lane was loaded onto Novex NuPAGE 10\% Bis-Tris midi gels (\#WG1202) and NuPAGE MES SDS running buffer (\#B0002) with NuPAGE Antioxidant (\#NP0005) added to the upper chamber. Gels were run at $200 \mathrm{~V}$ for $35-40 \mathrm{~min}$ and then stained using Coomassie Blue G-250 or SimplyBlue ${ }^{\mathrm{TM}}$ SafeStain (Invitrogen \#LC6060) as per the manufacturer's protocol.

2.8. Gel Quantification and Statistical Analysis. To quantify the overall efficiency of in vitro digestion as well as compare and rank treatments, the SDS PAGE gels were scanned with a CS-900 densitometer and analysed by Image Lab software (Bio-Rad).
For experiments 1 and 4, we calculated the relative digestibility. This was calculated by summing the density of all bands in a gel lane $>10 \mathrm{kDa}$ and then normalising to (i.e., dividing by) the summed density of bands in the respective T0 lane (timepoint 0, prior to digestion activation). Analysis of variance (ANOVA) was performed on this point estimate using Genstat software (17th Edition, VSN International, 2014). Pairwise $t$-test comparison of the means was obtained using the standard error of a difference from ANOVA. For Experiments 2 and 5, we extracted the gel densities and created plots of the spectral signals of these to allow visual comparisons.

\section{Results}

The effects of intrinsic and extrinsic factors on the in vitro digestibility of proteins and peptides in beef muscle and organ meats were evaluated.

3.1. Animal Age. Figure 2 shows that beef protein was highly digestible regardless of the age of animal from which the meat was collected (4-day-old calf, 18- to 24-month-old bull, or 6-year-old cow). There were some differences in size and quantity of proteins that were extracted from the cooked meat during sample preparation. For instance, the lanes at T0 (prior to digestion) show that extractability of connective tissue proteins (collagen-related proteins) with molecular weight $>260 \mathrm{kDa}$ tended to decrease with age (calf $>$ bull $>$ cow), suggesting greater solubility of the connective tissue proteins in younger animals. There was a strong band of protein at $17 \mathrm{kDa}$ that was present for bull and cow but absent for calf, suggesting underdeveloped myoglobin. At the end of the 120-minute gastric phase, overall digestibility was in the order calf $<$ bull $<$ cow (Figures 2 and 3 ).

3.2. Rigor State. The time of sampling of LD muscle (prerigor, from $50 \mathrm{~min}$ through $200 \mathrm{~min}$ postmortem) had little influence on the digestibility of beef proteins, and this was not markedly affected by rigor at $48 \mathrm{~h}$. Typical results for T60 of the gastric phase are shown in Figure 4, in this case for two bulls that had low ultimate $\mathrm{pH}$ values of 5.63 and 5.71. Major muscle proteins were all well digested by $60 \mathrm{~min}$, including myosin heavy chain, $\alpha$-actinin, and actin (approximately 250,100 , and $42 \mathrm{kDa}$, respectively). Likewise, small proteins and peptides of 30 to $10 \mathrm{kDa}$ were uniformly well digested. One minor difference was observed between the prerigor sampling times and the postrigor sample; a band near $40 \mathrm{kDa}$ seemed less digested (darker) postrigor.

3.3. Ultimate $p H$. The proteins of high ultimate $\mathrm{pH}$ meat digested faster than their low ultimate $\mathrm{pH}$ equivalent. Typical results for T0 through T60 of the gastric phase are shown in Figure 5. Densitometry measurements of each gel lane were used to calculate digestion efficiencies and rates for each of the treatment combinations $(n=49$, data not shown). Physiological and biochemical mechanisms 


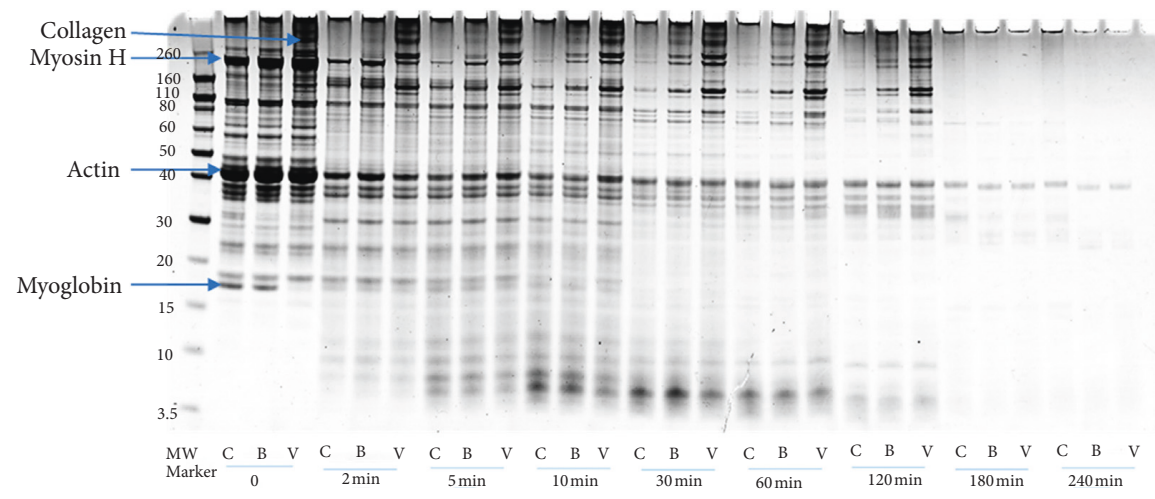

FIGURE 2: Experiment 1: SDS PAGE showing the effect of age of cattle on the digestibility of protein in cooked semimembranosus from cow (C), bull (B), and calf (veal, V). Results of gastric and intestinal phases for the pooled samples from 7 animals per age are presented as examples.
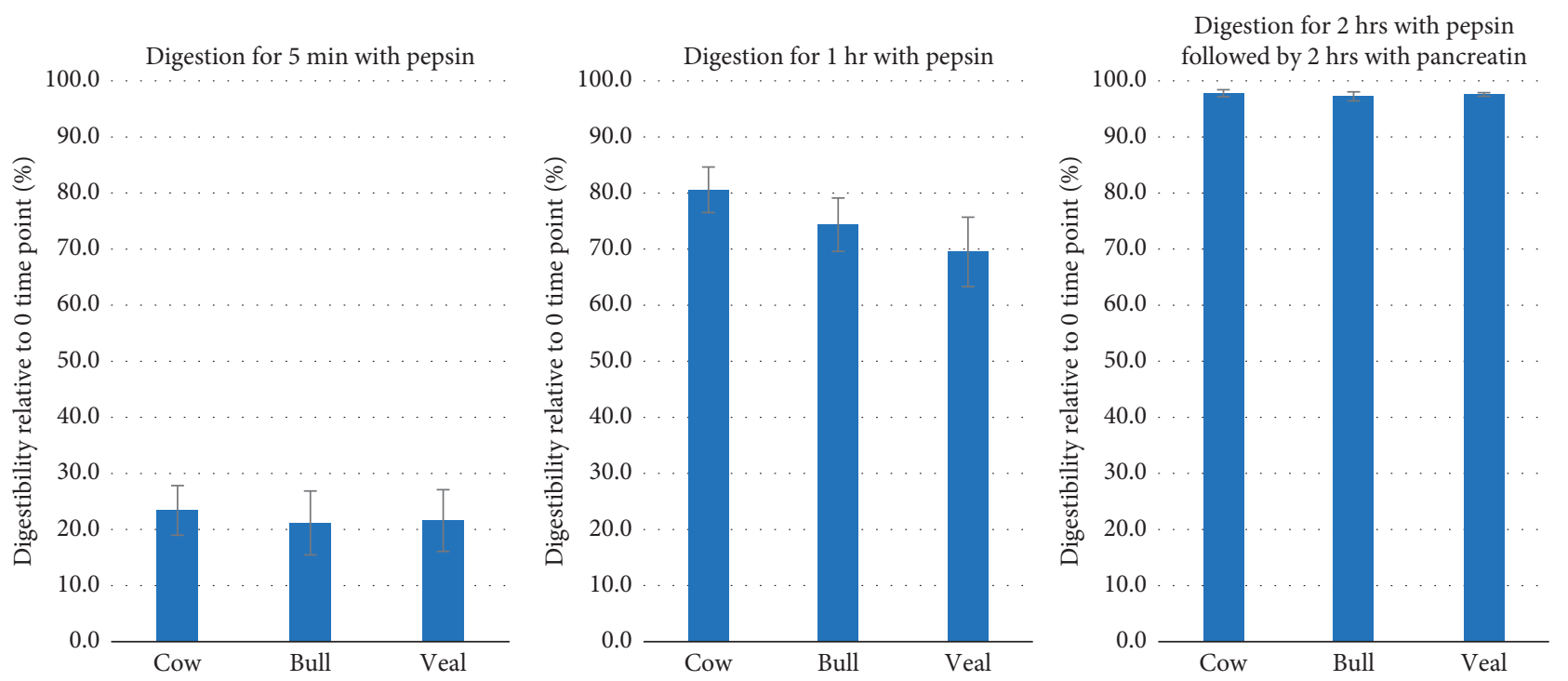

Figure 3: Experiment 1: the relative digestibility (see methods) of cooked semimembranosus from cow (C), bull (B), and calf (veal, V) at $5 \mathrm{~min}$ and one hour of gastric phase and two hours of intestinal phase. Results for the pooled samples from 7 animals per age are presented as examples.

underpinning the greater digestibility of high ultimate $\mathrm{pH}$ beef have been discussed by Farouk et al. [6].

3.4. Muscle/Meat Cut. The digestibility of proteins from different muscles and meat cuts from prime beef heifers was compared. Typical results for T0, T5, and T60 of the gastric phase and T240 of the intestinal phase are shown in Figure 6, in this case for four groups of muscle tissue. While there were few differences up to $5 \mathrm{~min}$, by $60 \mathrm{~min}$ supraspinatus appeared more digested (fewer and fainter protein bands), suggesting that this cut might be faster and more thoroughly digested.

3.5. Mincing/Particle Size. There was little effect of particle size on the digestibility of cooked proteins in meat. Figure 7 shows the response of bull beef for subsamples of LD taken at $50 \mathrm{~min}$ prerigor and $48 \mathrm{~h}$ postrigor timepoints and either finely ground or coarsely smashed. Exposure of meat proteins to pepsin activity in vitro should have been much greater for the finely milled substrate, yet this did not markedly influence the rate or extent of proteolysis. Some protein bands, for instance, near $100 \mathrm{kDa}$ and $40 \mathrm{kDa}$, did appear to digest more in the milled samples from T30 to T60; however, this was not consistent between animals.

3.6. Organ Meats. The structure and composition of organ meats is substantially different from muscle meat, and this has consequences for digestion. For instance, the protein content of the heart, kidney and spleen from prime steers was $10-27 \%$ less on a fresh-weigh basis (Table 1). Digestion commenced at a significantly faster pace for the kidney and liver compared to muscle, when evaluated as the relative digestibility of T5. However, by T60 and T240, there was no significant difference in digestibility between any of the tissues. The lower molecular weight and globular nature of the kidney and liver proteins likely contribute to their faster in vitro digestibility [10]. 


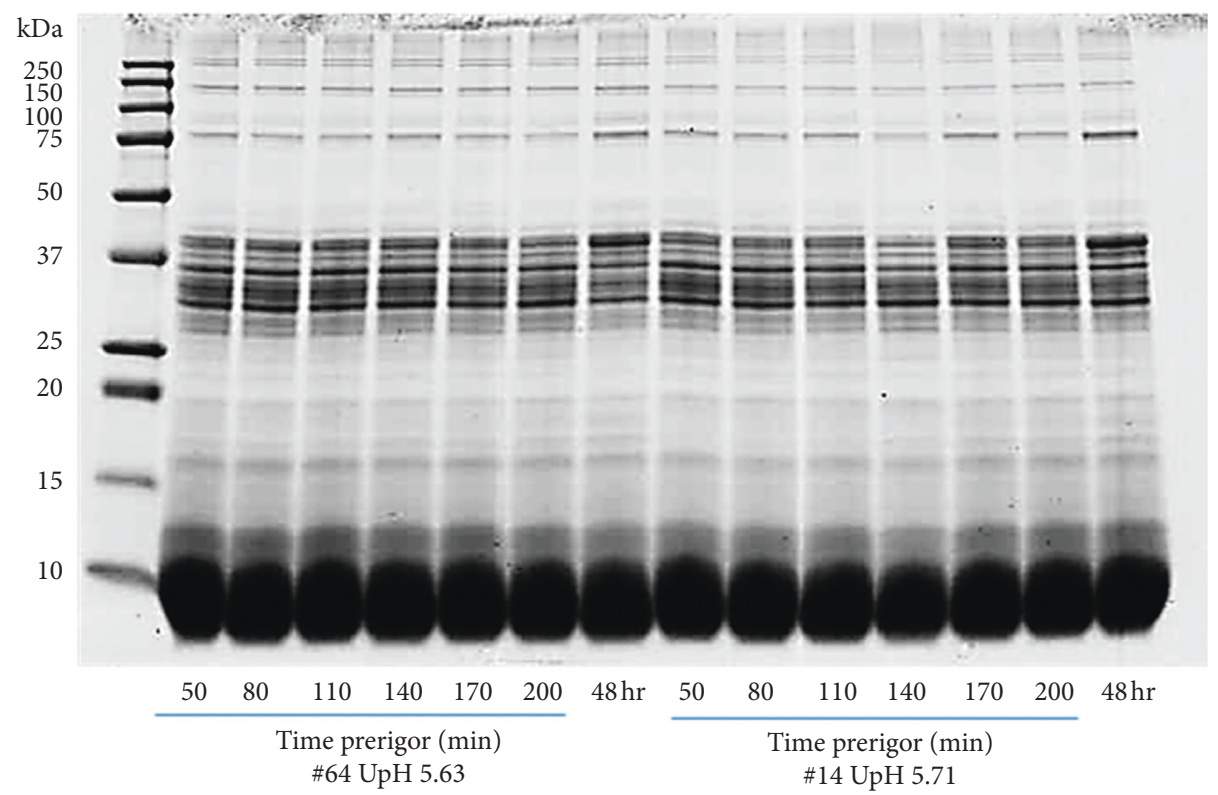

FIGURE 4: Experiment 2: SDS PAGE showing the effect of pre- and postrigor sampling time on the digestibility of protein in cooked M. longissimus dorsi from bull beef. Results at T60 of gastric phase for two of the 48 animals in this experiment are presented as examples.

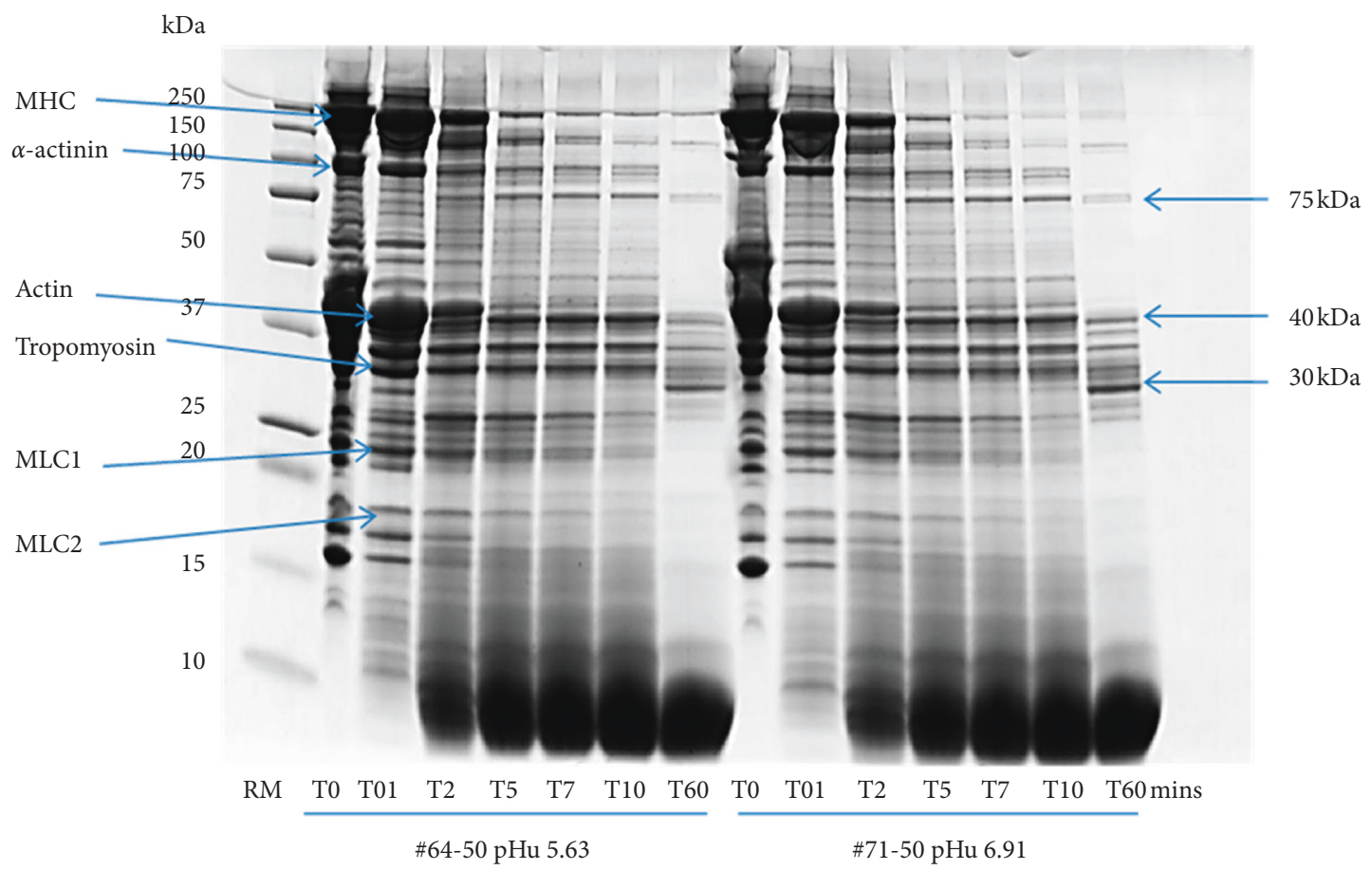

Figure 5: Experiment 2: SDS PAGE showing the effect of ultimate $\mathrm{pH}$ ( $\mathrm{pHu}$ ) on the digestibility of protein in cooked M. longissimus dorsi from bull beef. Results during the gastric phase for the sampling timepoint from two of the seven animals in this experiment are presented as examples.

3.7. Meat Accompaniments. The online survey of menus from New Zealand and Australia restaurants revealed that the most common accompaniments served with red meat were potato, onion, mushroom, tomato, rice, noodle, bean, and carrot (Figure 1). This varied slightly by country and markedly by cuisine. For instance, in New Zealand, noodle, rice, and bean were more popular at Asian restaurants, while potato, mushroom, and tomato were more popular with European cuisine.

SDS PAGE separation of proteins and peptides in the digesta of beef cooked with the top five accompaniments plus pumpkin showed that meats from all three age categories of animals (4-day-old calf, 18- to 24-month-old bull, or 6-year-old cow) were most digestible when cooked 


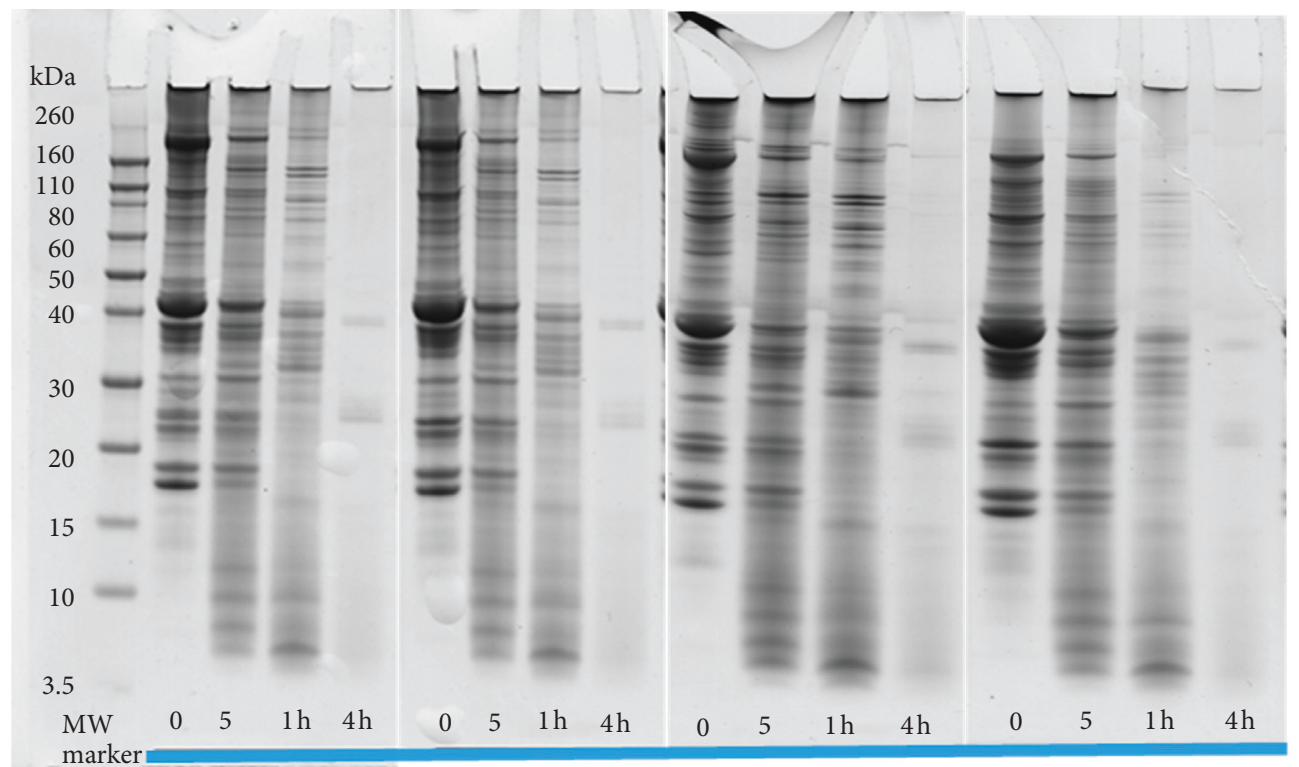

FIGURE 6: Experiment 3: SDS PAGE showing the effect of muscle type/cut on the digestibility of protein in cooked meat from prime heifers. Result at T0, T5, and T60 of gastric phase and T240 of intestinal phase for one of the five animals in this experiment are presented as examples. L to R extensors and flexors, rhomboideus, infraspinatus, and supraspinatus.

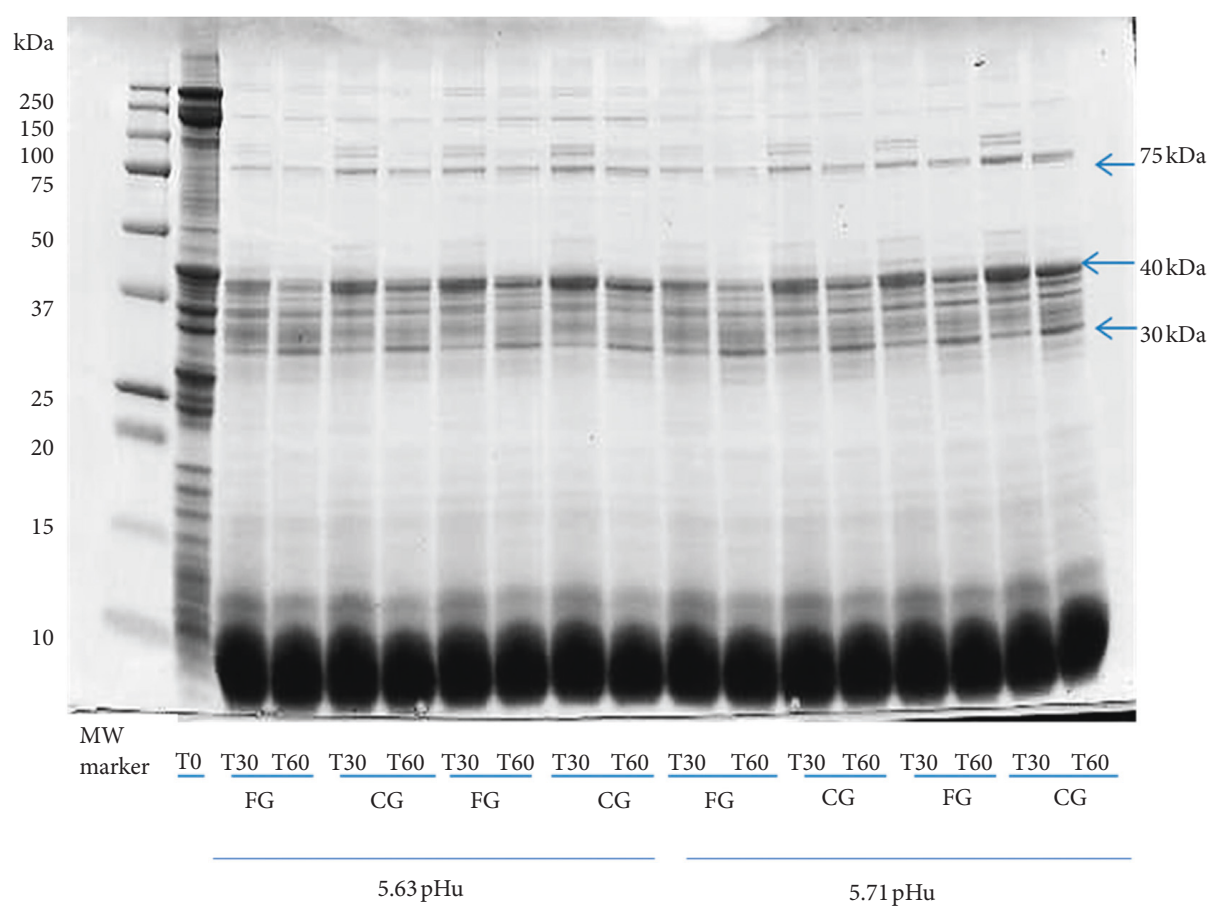

FIGURE 7: Experiment 2: SDS PAGE showing the effect of mincing/particle size on the digestibility of protein in cooked M. longissimus dorsi from bull beef. Results at T0, T30, and T60 of gastric phase for the two low pHu animals in this experiment are presented as examples. $\mathrm{FG}=$ finely ground; $\mathrm{CG}=$ coarsely ground.

with mushroom, whereas digestion was least efficient when the meats were cooked with rice and potatoes. Based on relative digestibility calculation and averaging over all animal ages, the rank order of protein digestibility was found to be mushroom $>$ pumpkin $>$ onion $=$ tomato $>$ rice $>$ potato. Figure 8 presents an example with bull meat and shows that cooking meat with mushrooms was very effective in promoting digestion through the gastric and intestinal phases.
In contrast, meat cooked by itself did not digest completely even after $240 \mathrm{~min}$. Figure 9 shows the trace densities of beef cooked with the six accompaniments at T0 and T240 highlighting the extensive breakdown of the lower molecular weight proteins with mushroom and pumpkin compared to the other accompaniments.

Enhanced digestion from cooking with mushroom (and pumpkin) could be due to the presence of endogenous 
TABle 1: Experiment 4: protein content and digestibility of bovine organ meat and muscle meat.

\begin{tabular}{|c|c|c|c|c|c|c|c|}
\hline \multirow{2}{*}{ Attributes } & \multicolumn{4}{|c|}{ Organ meats } & \multirow{2}{*}{ Beef } & \multirow{2}{*}{ SED } & \multirow{2}{*}{$P$ value } \\
\hline & Heart & Kidney & Spleen & Liver & & & \\
\hline Protein (\%) & $18.43^{\mathrm{ab}}$ & $16.47^{\mathrm{a}}$ & $17.33^{\mathrm{a}}$ & $20.27^{\mathrm{bc}}$ & $22.73^{\mathrm{c}}$ & 1.21 & 0.001 \\
\hline $\mathrm{RD} @ 5 \mathrm{~min}$ & $54.68^{\mathrm{a}}$ & $73.90^{\mathrm{b}}$ & $45.01^{\mathrm{a}}$ & $84.06^{\mathrm{b}}$ & $56.34^{\mathrm{a}}$ & 6.11 & 0.001 \\
\hline RD@1h & $79.86^{\mathrm{ab}}$ & $82.53^{\mathrm{ab}}$ & $75.55^{\mathrm{a}}$ & $86.43^{\mathrm{b}}$ & $75.84^{\mathrm{ab}}$ & 5.30 & 0.05 \\
\hline RD@4h & $95.33^{\mathrm{ab}}$ & $91.98^{\mathrm{a}}$ & $94.50^{\mathrm{ab}}$ & $96.32^{\mathrm{b}}$ & $95.09^{\mathrm{ab}}$ & 3.10 & 0.006 \\
\hline
\end{tabular}

$\mathrm{RD}=$ relative digestibility; $\mathrm{SED}=$ standard error of difference; means in the same row bearing the same superscripts are not different $(P>0.05)$.

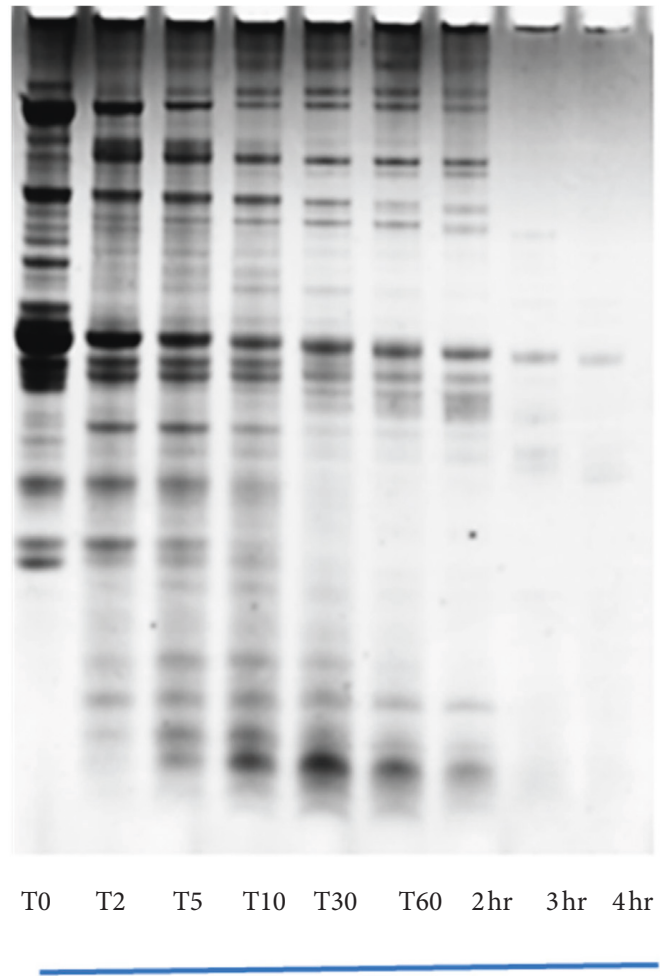

Digestion time (min)

Cooked bull beef only (no mushroom)

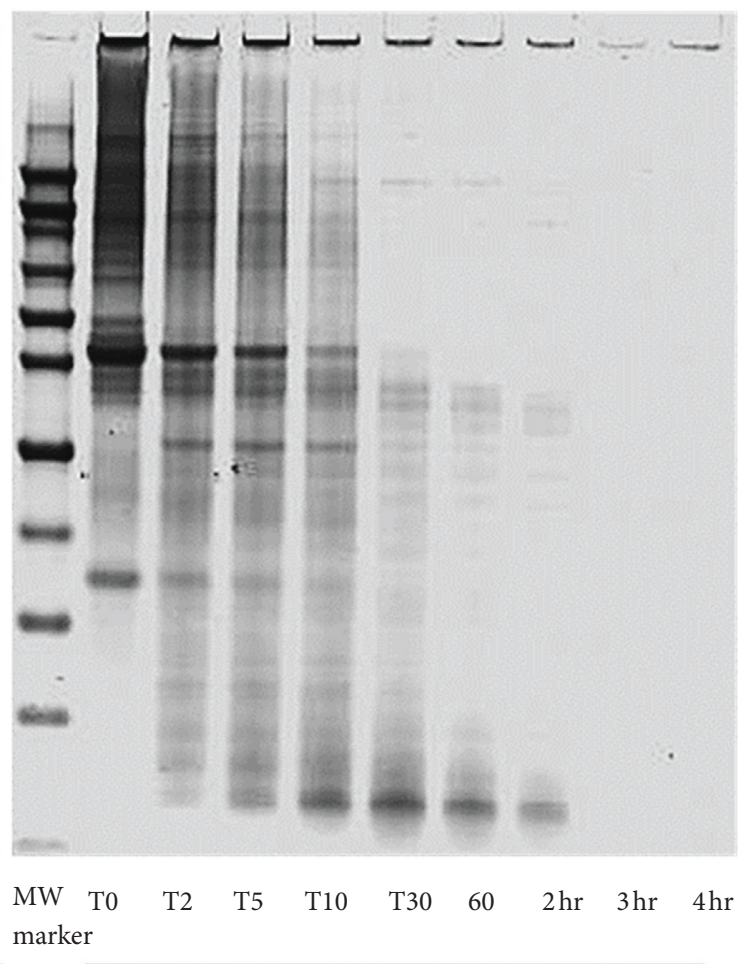

Digestion time (min)

Cooked bull beef + mushroom

FIGURE 8: Experiment 5: SDS PAGE showing the effect of vegetable accompaniments in a cooked "meal" containing semimembranosus from cow, bull, or calf on the digestibility of total proteins. Results of gastric and intestinal phases for the meal containing pooled bull meat from Experiment 1 with and without mushroom are presented as examples.

proteolytic enzymes in these vegetables that were not present in the other accompaniments as observed in the results (zymograms bands visible on gels but too faint when photographed, thus not included) of the zymogram gel separation of enzymes extracted from the six accompaniments which showed faint protease activity seen for pumpkin and mushroom and not for the other accompaniments.

\section{Discussion}

Meat is usually considered to be the skeletal muscle of animals, along with any attached fat, connective tissue, blood and blood vessels, and may also include organ tissues such as the liver, heart, kidney, and intestines [11]. It makes important contributions to a balanced diet because it is dense with essential nutrients [12-14]. While the gross composition of organ meat varies by tissue, its protein content is always different from skeletal muscle, with less of the myofibrillar fraction comprising structural proteins. The supply chain of meat from the time the animal is selected, slaughtered, sold, and prepared varies around the world in some respects. One major difference is that in developing countries where cold storage facilities are limited, meat is often cooked and consumed in a prerigor state, when it is still muscle before it is converted to meat. Another difference is that in the cuisine of many cultures, meat is cooked together with its starch and vegetable accompaniments, in contrast to Western style meal preparation where meat is often roasted and eaten separately as intact cuts. In addition, animal organ meat, sometimes referred to as offal or the fifth quarter of a carcass, is only a minor contribution to typical Western diets for a variety of reasons, thus missing out on its potential culinary and 


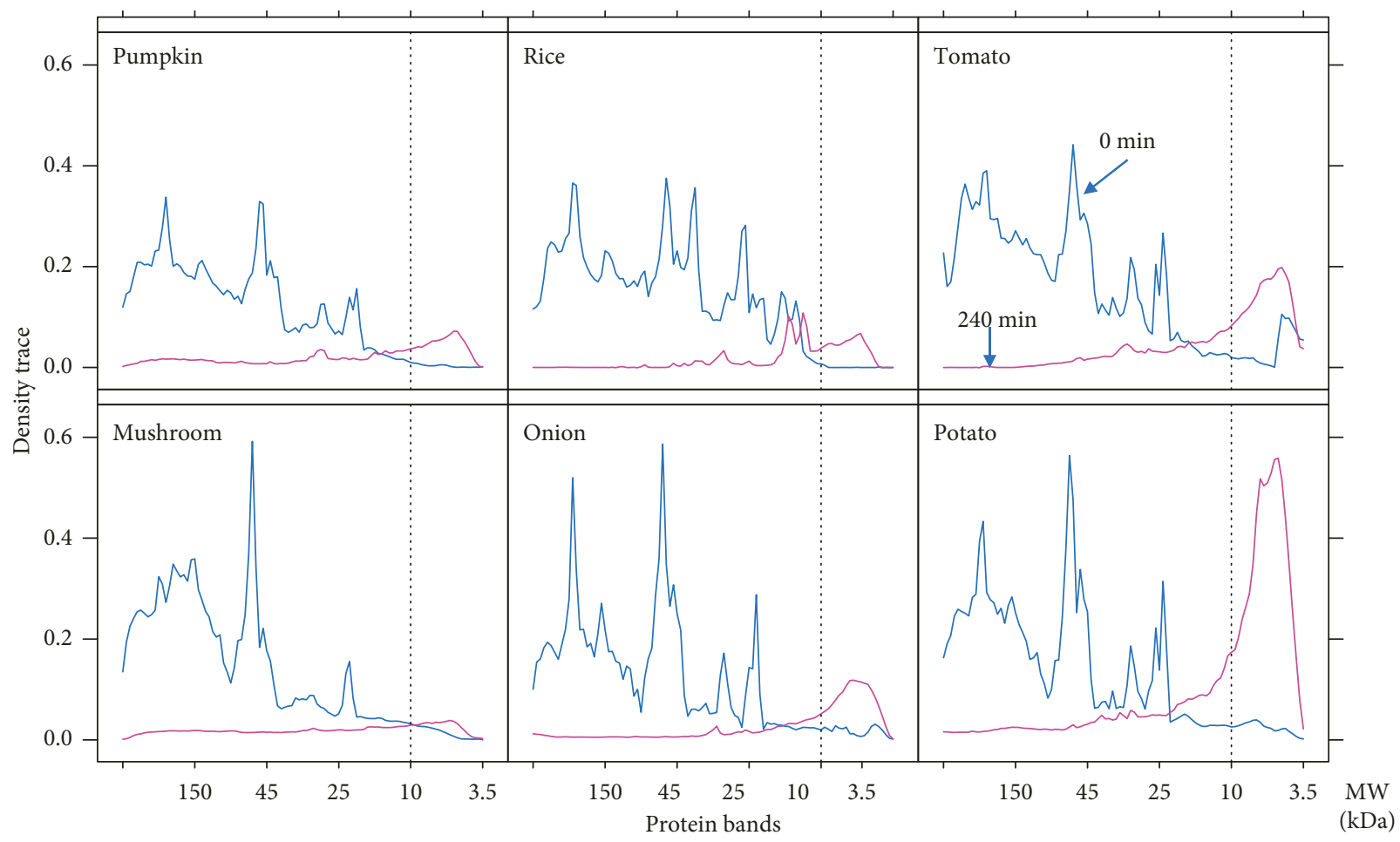

Figure 9: Experiment 5: density tracings of SDS PAGE showing the effect of vegetable accompaniments in a cooked "meal" containing semimembranosus from cow, bull, or calf on the digestibility of total proteins. Results at T0 of gastric phase and T240 of intestinal phase for meals containing pooled bull meat from Experiment 1 with six accompaniments are presented as examples.

nutritional values. Regardless of how meat is presented and consumed, the goal for the consumer is biologically available nutrition through the gateway of digestion. The rate and extent of meat digestibility and the factors affecting those processes are important determinants of the utilisation, differentiability, and value of meat [6].

We previously determined the effects of ultimate $\mathrm{pH}$, ageing, and cooking on beef digestibility and suggested that chefs could exploit the attributes to tailor the choice of muscle and preparation to the requirements of customers [6]. In the current study, we extend these factors to include animal age, muscle state of rigor, cut, particle size, organ meats, and meal accompaniments.

Age of livestock at slaughter is a significant determinant of meat functionality and eating quality, and it may also affect digestibility. Experiment 1 with three ages of beef demonstrated that when the relative digestibility of all the proteins resolved in Figure 2 including the resistant stromal proteins (collagen-related) were considered, it would appear digestibility increased with animal age (calf $<$ bull $<$ cow) (see T5 and T60 in Figure 3). This counterintuitive observation could be due to the high molecular weight connective tissue proteins that are more soluble in young tissue than old and consequently more extractable when the meat is prepared for assay [15]. Although soluble, the connective tissue substances are resistant to in vitro digestion with pepsin and so lowered the total relative peptic digestibility of calf beef compared to the older cattle when assessed using gel electrophoresis. Experiments 2 and 3 demonstrated that beef digestibility was not substantially affected by muscle state of rigor, or the type of cut, or how fine the meat was ground at the time of cooking. All three factors did have a minor influence on the proteolysis of resistant proteins near $42-$ $40 \mathrm{kDa}$, previously identified to be fragments of isoforms of myosin (myosin-1, myosin-2, and myosin-7). They were more digested (less intense) in prerigor bull beef than in $48 \mathrm{~h}$ postrigor, in less collagenous cuts compared to highercontaining cuts, and in finely ground milled meat compared to coarsely smashed meat. If those proteins were yardsticks or proxies for assessing beef digestibility, then prerigor, lowcollagen supraspinatus muscle finely ground prior to cooking would be judged more digestible than the alternatives in these experiments.

Sustainable production of animals as a source of food demands that we make full use of every carcass. Unlocking the potential of the less familiar cuts and promoting their inherent benefits is an important role for nutritional research. Experiment 4 demonstrated that beef organ meats/ offals such as liver and kidney were more digestible than muscle meat from the same carcass (Table 1). This suggests new opportunities for organ meat as a versatile ingredient, perhaps by formulating highly digestible animal protein foods for infants with less developed GIT or for elder consumers with compromised GIT function. The soft texture and minimal myofibril content of the liver and kidney also offer functionality. These could be a valuable resource for the 1 st and 3rd age consumer groups who struggle with chewing and swallowing muscle meat [16].

When meat is served at a meal, its accompaniments are usually chosen to provide a balance of nutrition or for 
culinary and gustatory purposes. Well-informed combining can also produce beneficial biochemical synergies. For instance, consuming orange juice that contains ascorbic and citric acids will enhance the bioavailability of ferric iron in plant foods [17]. It is possible that some accompaniments affect the digestion of food and so might be chosen to optimise benefits for a particular consumer or to better suit an occasion.

For Experiment 5, we decided that the "best" accompaniments to study were those in wide and common use. A survey of meal designs in restaurants provided insight and objective measures, although perhaps biased towards luxury and indulgence eating. The top accompaniments were potato, onion, mushroom, tomato, and rice (Figure 1), with $32 \%$ of the accompaniments cooked with meat and $68 \%$ served alongside.

Although the present study was not designed to determine the effect of cooking per se, it is important to note that cooking meat on its own has variable effects on meat digestibility depending on both temperature and time. For instance, peptic digestibility of beef is lowered, and pancreatic digestibility is enhanced when meat is cooked quickly to $100^{\circ} \mathrm{C}$, with longer cooking at the same temperature reducing overall susceptibility of meat proteins to proteolytic enzymes; cooking pork mildly at $70^{\circ} \mathrm{C}$ enhanced peptic digestion, while at $100^{\circ} \mathrm{C}$ slowed peptic digestion [3-5]. In the present study, the combined meat and accompaniments were cooked at $100^{\circ} \mathrm{C}$; cooking at this temperature with some of the accompaniments improved the digestibility of muscle meat from animals of all ages; Figure 8 shows how mushroom affected the bull beef. Note that even the resistant proteins near $42-40 \mathrm{kDa}$ were digested by T30. A zymogram of the enzymes in extracts of accompaniments revealed proteolytic enzymes in mushroom and pumpkin. These enzymes may be contributing to digestibility. Mushroom and pumpkin are known to contain proteolytic enzymes $[18,19]$, but their effects on wholetissue digestion had not been demonstrated.

\section{Conclusions and Implications}

Within the parameters of the present study, beef was observed to be more digestible or digested faster when it came from an older animal, at prerigor, and when it had high ultimate $\mathrm{pH}$ or contained less collagen content. Some beef organ meats were more digestible than beef muscle. Digestibility improved when meat was cooked with vegetables that contain proteolytic enzymes and diminished slightly with carbohydrate-rich or starchy foods such as rice and potatoes.

These results help to support a rational basis for the design of prepared meals where meat protein is a central ingredient, such as ready meals, institutional catering, and novel product categories of foods. Formulating around digestion functionality creates opportunities for speciality foods suited to infants and elder consumers. These are novel, value-adding ways to make the nutrition of meat more widely available and to stimulate sustainable utilisation of the entire carcass.

\section{Data Availability}

The data used to support the findings of this study are available from the corresponding author upon request.

\section{Conflicts of Interest}

The authors declare that they have no conflicts of interest.

\section{Acknowledgments}

This work was supported by grants from governmental contestable funding pools (NZ Ministry of Science and Innovation and later the NZ Ministry of Business, Innovation and Employment) and the AgResearch Strategic Science Investment Fund (contract A19119). The authors are grateful for valuable assistance in the field and laboratory from the AgResearch technical staff Kevin Taukiri and Ancy Thomas and from the University of Waikato student interns Oliver Cook, Hannah VanderWoude, and Georgia Clements, and from the French intern Fanny Badée.

\section{References}

[1] M. L. Bax, C. Buffière, N. Hafnaoui et al., "Effects of meat cooking, and of ingested amount, on protein digestion speed and entry of residual proteins into the colon: a study in minipigs," PLoS One, vol. 8, no. 4, Article ID e61252, 2013.

[2] P. Restani, A. R. Restelli, A. Capuano, and C. L. Galli, "Digestibility of technologically treated lamb meat samples evaluated by an in vitro multienzymic method," Journal of Agricultural and Food Chemistry, vol. 40, no. 6, pp. 989-993, 1992.

[3] V. Santé-Lhoutellier, T. Astruc, P. Marinova, E. Greve, and P. Gatellier, "Effect of meat cooking on physicochemical state and in vitro digestibility of myofibrillar proteins," Journal of Agricultural and Food Chemistry, vol. 56, no. 4, pp. 1488-1494, 2008.

[4] L. Kaur, S. M. Rutherfurd, P. J. Moughan, L. Drummond, and M. J. Boland, "Actinidin enhances protein digestion in the small intestine as assessed using an in vitro digestion model," Journal of Agricultural and Food Chemistry, vol. 58, no. 8, pp. 5074-5080, 2010.

[5] M.-L. Bax, L. Aubry, C. Ferreira et al., "Cooking temperature is a key determinant of in vitro meat protein digestion rate: investigation of underlying mechanisms," Journal of Agricultural and Food Chemistry, vol. 60, no. 10, pp. 2569-2576, 2012.

[6] M. M. Farouk, G. Wu, D. A. Frost, S. Clerens, and S. O. Knowles, "The in vitro digestibility of beef varies with its inherent ultimate $\mathrm{pH}, "$ Food Function, vol. 5, no. 11, pp. 2759-2767, 2014.

[7] C. P. Pirovani, H. A. S. Carvalho, R. C. R. Machado et al., "Protein extraction for proteome analysis from cacao leaves and meristems, organs infected by Moniliophthora perniciosa, the causal agent of the witches' broom disease," Electrophoresis, vol. 29, no. 11, pp. 2391-2401, 2008.

[8] M. Minekus, M. Alminger, P. Alvito et al., "A standardised static in vitro digestion method suitable for food-an international consensus," Food Function, vol. 5, no. 6, pp. 1113-1124, 2014.

[9] T. Bohn, F. Carriere, L. Day et al., "Correlation between in vitro and in vivo data on food digestion. What can we predict 
with static in vitro digestion models?," Critical Reviews in Food Science and Nutrition, vol. 58, no. 13, pp. 2239-2261, 2017.

[10] P. Ercan and S. N. El, "Changes in content of coenzyme Q10 in beef muscle, beef liver and beef heart with cooking and in vitro digestion," Journal of Food Composition and Analysis, vol. 24, no. 8, pp. 1136-1140, 2011.

[11] M. M. Farouk, M. J. Y. Yoo, N. S. A. Hamid, M. Staincliffe, B. Davies, and S. O. Knowles, "Novel meat-enriched foods for older consumers," Food Research International, vol. 104, pp. 134-142, 2018.

[12] P. M. d. C. C. Pereira and A. F. d. R. B. Vicente, "Meat nutritional composition and nutritive role in the human diet," Meat Science, vol. 93, no. 3, pp. 586-592, 2013.

[13] P. Williams, "Nutritional composition of red meat," Nutrition \& Dietetics, vol. 64, no. S4, pp. S113-S119, 2007.

[14] R. R. Wolfe, S. M. Rutherfurd, I.-Y. Kim, and P. J. Moughan, "Protein quality as determined by the digestible indispensable amino acid score: evaluation of factors underlying the calculation: table 1," Nutrition Reviews, vol. 74, no. 9, pp. 584599, 2016.

[15] M. Shimokomaki, D. F. Elsden, and A. J. Bailey, "Meat tenderness: age related changes in bovine intramuscular collagen," Journal of Food Science, vol. 37, no. 6, pp. 892-896, 1972.

[16] C. G. Forde, N. van Kuijk, T. Thaler, C. de Graaf, and N. Martin, "Oral processing characteristics of solid savoury meal components, and relationship with food composition, sensory attributes and expected satiation," Appetite, vol. 60, no. 1, pp. 208-219, 2013.

[17] D. Ballot, R. D .Baynes, T. H. Bothwell et al., "The effects of fruit juices and fruits on the absorption of iron from a rice meal," British Journal of Nutrition, vol. 57, no. 3, pp. 331-343, 1987.

[18] M. Nakamura, A. Iketani, and Y. Shioi, "A survey of proteases in edible mushrooms with synthetic peptides as substrates," Mycoscience, vol. 52, no. 4, pp. 234-241, 2011.

[19] T. S. Jin, "Isolation and characterization of enzyme protease from pumpkin and its affinity to different protein substrates," Project Report, Department of Chemical Science, Universiti Tunku AbdulRahman, Petaling Jaya , 2016, http://eprints.utar. edu.my/2340/1/CE-2016-1300713-1.pdf. 


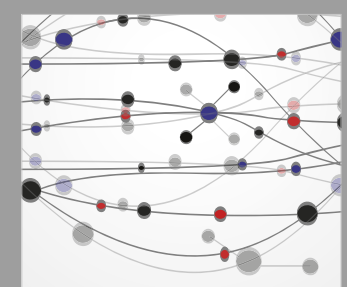

The Scientific World Journal
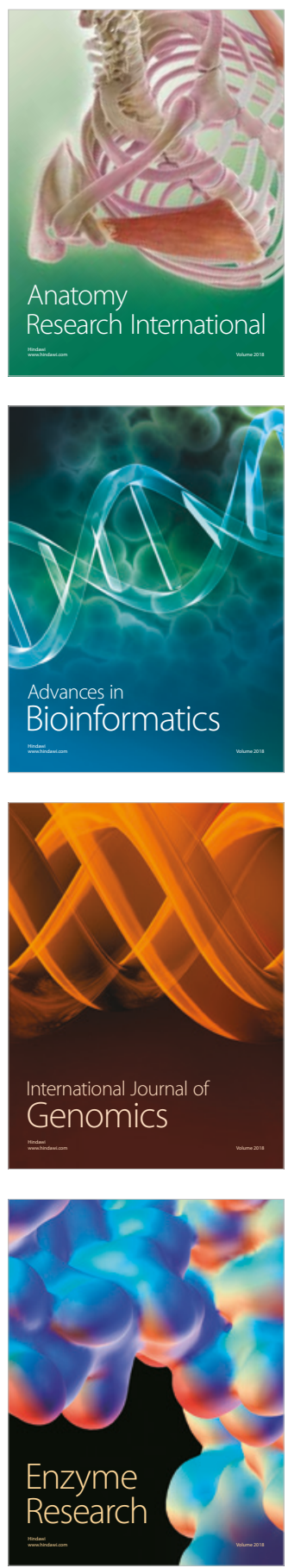
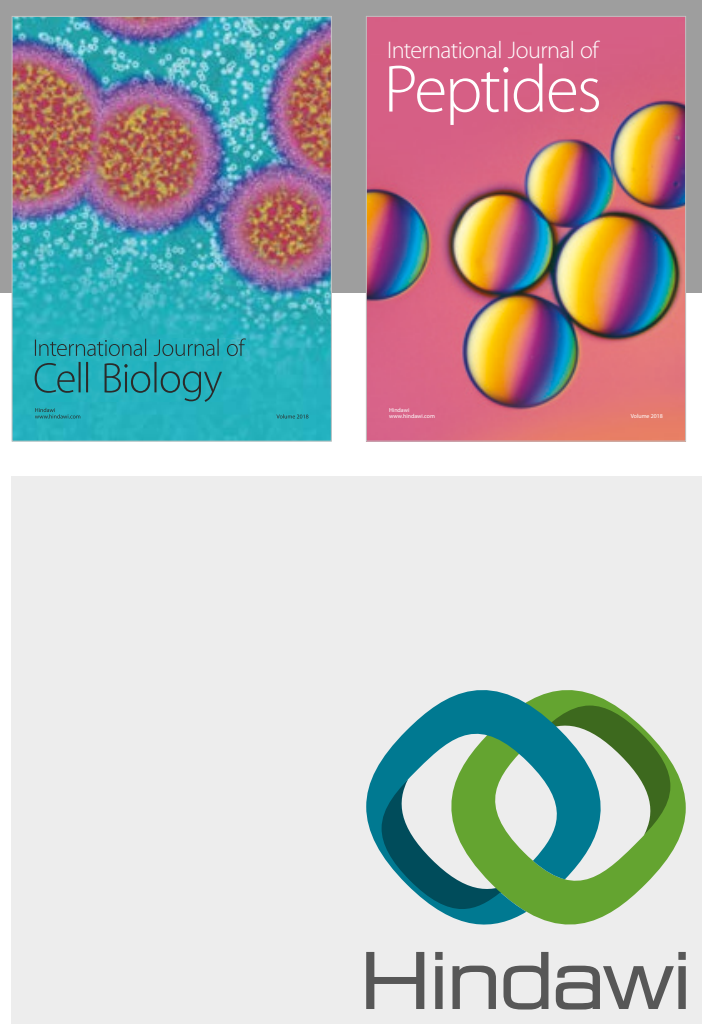

Submit your manuscripts at

www.hindawi.com
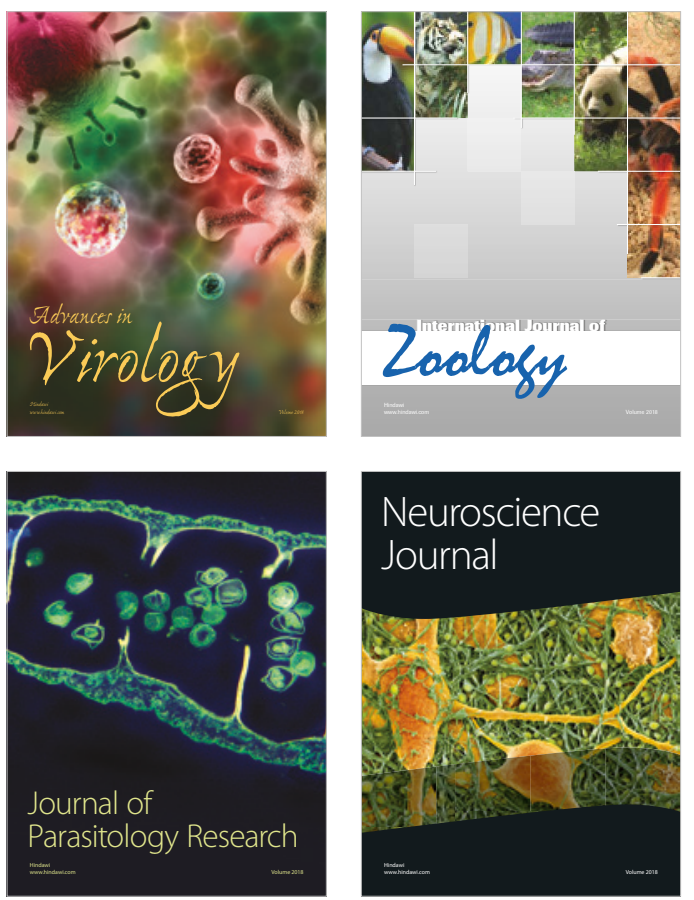
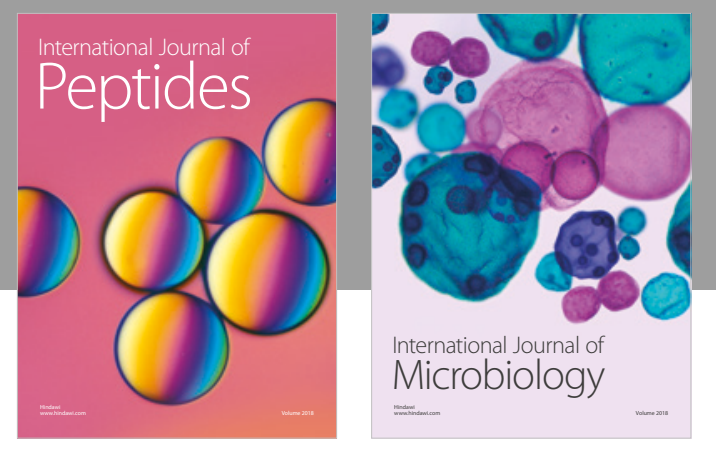

nternational Journal of Microbiology
Journal of
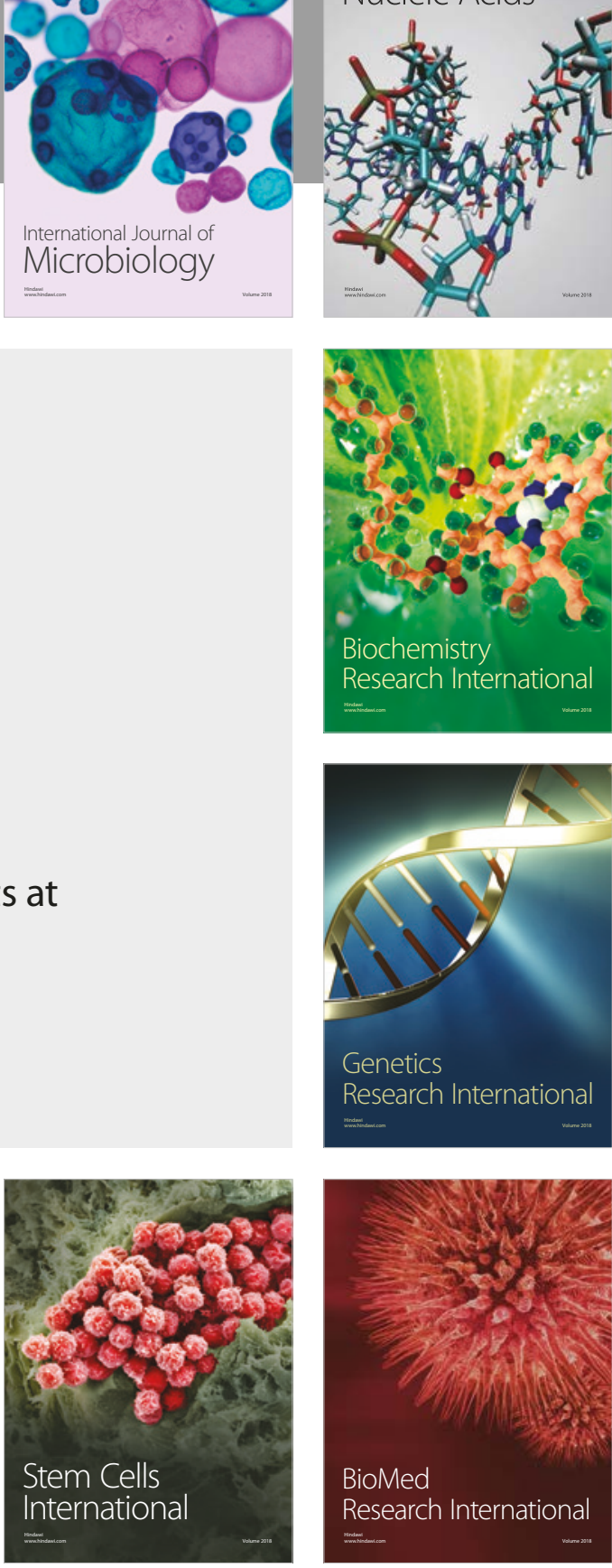
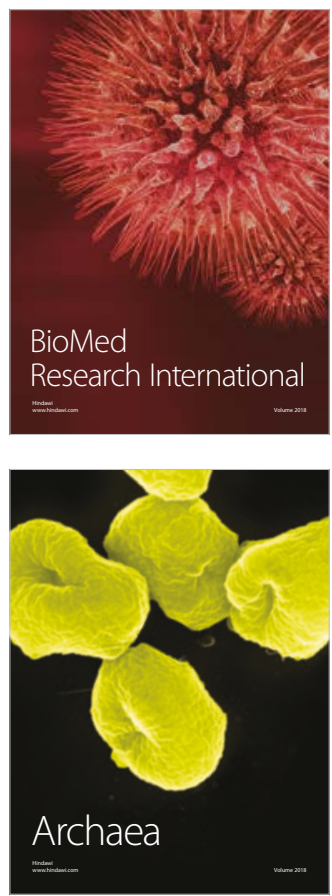